\title{
Forest Entomology Challenges of the 80's'
}

by

\section{J. H. Cayford ${ }^{2}$}

Premier Brian Peckford of Newfoundland said in February, 1981 that he has reluctantly accepted a Royal Commission's recommendation that chemical sprays be used to fight a spruce budworm infestation that could eliminate the province's forest industry within a decade. Peckford said the chemical matacil will be used in 1981 to spray about one million acres of forest at a cost of $\$ 4.5$ million. The Royal Commission says there is no evidence any of the available chemicals, such as matacil, fenitrothion or acephate, are dangerous to humans.

In early April 1978, Premier Regan of Nova Scotia firmly rejected a recommendation of a task force on wood allocation and forest management in Nova Scotia. The recommendations called for limited spraying for foliage protection, to be repeated until the budworm epidemic collapsed. The Premier stated "frankly, we're so strongly opposed to the aerial spraying of insecticides that I can't conceive reopening the debate." This decision reinforced a decision made a year earlier when "the Nova Scotia cabinet decreed that because of the possible hazard to public health and to the environment, aerial spraying of chemical insecticides will not be permitted.'

The two foregoing statements, represent your most significant challenge of the 1980's. You have some tools for forest pest management but in many instances are unable to use them. Accordingly, you need either new techniques or you need to educate the public in such a manner that you will be able to use existing techniques. I would suggest that you need action in both areas if the forest resource is to be protected from economically important damage as a result of forest insects.

I have been asked to speak to you on some challenges facing entomologists in the 1980's. My first challenge is quite simple - forest entomologists must become part of the forest community. For too long, forest entomologists have seemed neither fish nor fowl - you are but a small component within the entomology scene, with most attention paid to agricultural entomology, and you are but a small component within the forestry scene.

I have a few specific points to make that indicate the relatively low profile of forest entomology and forest entomologists in this country.

(1) At one time, forest entomologists played an important management role within the Canadian Forestry Service. Now, however, only 4 of our 12 senior positions are occupied by entomologists. Not too many years ago, forest entomologists were the dominant force within our forest insect and disease survey. Now the Director of the survey and five of six unit heads are forest pathologists.

(2) At the Canadian Forest Congress held in September 1980 the paper on insects and diseases was presented by a silviculturist, Dr. Gordon Baskerville. Indeed, Dr. Baskerville is one of the major spokesmen on the spruce budworm.

(3) At the University of Toronto, Faculty of Forestry, there is no forest entomologist among the permanent staff. At Lakehead, both forest entomology and forest fire are taught by the same staff member.

(4) In Mid-February, I attended a major forest conference in New Brunswick sponsored by 3 forestry associations,

${ }^{1}$ Paper presented at 32nd Annual Western Forest Insect Work Conference, Banff, Alberta, March 2-4, 1981

${ }^{2}$ Director General, Research and Technical Services, Canadian Forestry Service, Ottawa. the Canadian Institute of Forestry, the New Brunswick Forest Products Association and the New Brunswick Association of Registered Professional Foresters. About 150 foresters were in attendance - but I saw only 5 entomologists. Of these, one is retired, two are no longer in entomology, while the other two are nearing retirement. Yet, the most important forestry problem in New Brunswick is the spruce budworm.

(5) The Canadian Institute of Forestry is the major national forestry organization in Canada. It is roughly comparable to the Society of American Foresters. Yet membership by our forest entomologists is very low. Within the Forest Pest Management Institute, a major National Institute, only 2 of 26 professionals are members. Of the 4 entomologists who are CFS Directors, 2 are not members of the CIF and most of our research scientists in entomology do not belong to the organization.

In contrast to forest entomologists, I believe that forest pathologists are well integrated into the forestry community. The difference may well be that the majority of our pathologists have a forestry degree, while the majority of our entomologists have a science degree. What we seem to need is a renewed awakening of entomology within our forestry schools where entomology is at a low ebb.

The time is now appropriate for you to move out of your forest entomology mold and to stand up and be counted amongst foresters. It is widely accepted that forest protection is an integral part of forest management. Indeed without protection, there is little rationale for management. And with an increase in man-made forests, and in intensive forestry, we are bound to encounter more and more forest pest problems. Specific examples here are the black army cutworm outbreaks in British Columbia in stands planted immediately after slash burning and the rapidly escalating importance of seed and cone insects attacking seed orchards.

My second challenge relates to the need for new biological techniques for forest pest management, and the need to refine our knowledge on those most promising techniques. The Baskerville Task Force Report of 1976 concluded that there was no real alternative to chemical spraying. However, one biological insecticide, Bacillus thuringiensis (B.t.) was considered operational. Baskerville went on to say:

"use of B.t. may be indicated where some protection is desirable and the use of chemicals is precluded for environmental or social reasons, but it is not, at present, considered an adequate substitute for chemical insecticides in large-scale crop protection."

From my perspective, the situation described in November 1976 has not really changed, some $4-1 / 2$ years later. Accordingly, I would challenge you to take stock of the current situation; assess what we know with respect to B.t., determine what we should know and develop programs to fill the knowledge gap. This topic must be pursued with vigor as forest managers are anxious to add B.t. to their arsenal of techniques in the fight against spruce budworm. There is also a need to pursue with vigor the use of pheromones. While several trials have been carried out, there seems to me to have been no overall strategy of pheromone research in Canada. You should also not ignore the opportunities that may be afforded through mass production and liberation of parasites and predators and through development of integrated pest management strategies that will involve the use of forest management practices as well as direct control methods. 
Challenge number three deals with the need to obtain more information on the human health aspects of forest protection programs. Concern for human health first became evident when it was postulated that a rare children's disease, Reye's Syndrome, was thought to be linked with spruce budworm spraying. Although this particular hypothesis has not been verified, the concern for human health continues to this day, and is a major factor to be considered insofar as the future use of chemical spraying as a forest management tool. Research on human health effects is beyond the scope of conventional forest entomological research programs and accordingly in the CANUSA spruce budworms research program has been given little consideration. There is a need for forest entomologists to play a leading role in promoting and inspiring medical research on the effects of forest insecticide spraying. Research might be first directed to those workers who are intimately associated with the spray programs. Both the CANUSA Program Managers and the Eastern Canada Spruce Budworm Council are currently trying to develop a more collaborative approach with government health authorities.

My fourth challenge to you is to learn more about the technology of large-scale aerial spraying - basically to develop improved strategies for chemical insecticide application.

Research in the pest management field is continually being directed towards alternatives to chemical control. There is, however, a serious concern among resource managers, that in our quest for biological control products, emphasis on improving those tools that we already have is lagging. As many land managers see it, the options that they already have are in peril. There is a major link between the human health issues that face aerial control operators and the efficiency of existing delivery mechanisms. It is well documented that with our present spray technology, only a proportion of the emitted volumes reach the target protection area, and an even smaller proportion impacts in the range of the pest insect. It follows that the remainder, known as off-target drift, adds an unnecessary pollution level to the surrounding area. It is to this off-target aerosol of insecticide that the greatest human health risk criticisms are directed. The challenge, and one that many feel we must respond to rapidly or lose the chemical option entirely, is to refine the delivery system and formulations in such a manner as to direct all, or the vast majority of the spray emissions to impact on the target areas. This would entail a revamping of the aircraft hardware, a better understanding of spray droplet behaviour, and the optimum formulation characteristics to achieve the desired results. It has been noted that despite the enormous sums being spent annually against the eastern budworm in chemical spray programs, spray application and drift have so far received scant attention in CANUSA programs. Fortunately, I feel we are making some progress here with recently announced programs by the New Brunswick Research and Productivity Council and by the Canadian Forestry Service.

The fifth challenge is to develop multi-disciplinary research teams to address forest insect problems. Thus, the spruce budworm should be considered in the context of a forest management problem rather than as an entomological problem. A review of CFS research projects indicates that by and large the entomological program is structured on a discipline basis. For example at the Great Lakes Forest Research Centre, there are projects dealing with both spruce budworm and with the management of spruce-fir forests. Multi-disciplinary research teams might well include specialists in such disciplines as forest entomology, forest pathology, silviculture, ecology, soils, and tree physiology and would focus on forest management problems of a given forest tree species or cover type.
Challenge six is the need to develop improved damage appraisal systems in order that losses from forest pests may be quantified and that loss statistics can be integrated with provincial inventory statistics to provide regional and national estimates of losses from insects and diseases. The forest insect and disease survey of the CFS is making an encouraging start in this direction but there is still a cy for the survey to focus on insects and diseases, rather than on trees and forests. We also need better information on the prediction of losses over a 5- to 10-year time frame and we need more detailed information that will enable us to predict the future development of individual trees after insect or disease attack.

Challenge seven is the need to apply information already known. This is a challenge not only for entomologists, but also for forest managers; failure to utilize available information is a reflection on both the researcher and the user alike. I believe we already have a lot of information available that is not being used. The challenge is for the research agencies to place increased emphasis on technology transfer, while management agencies must develop the entomological expertise needed to put research into practice.

Challenge eight is of particular concern to the CFS, but probably also to other major employers of entomologists. Basically, the age distribution of entomologists is skewed towards the older age classes. In view of the low level of current entomological graduate training in Canada, and particularly in forest entomology, it will be difficult to replace our older, experienced entomologists. In the 1980's many entomologists will be leaving the CFS, and their years of experience will be lost. Before these specialists retire, we should undertake a concerted effort to avoid the irreplaceable loss of the experience of a generation of en. tomologists. It is possible that the knowledge and experience of these scientists could be captured in computer simulations, which offer a convenient and useful "archiving" medium.

The ninth and final challenge is the need to increase our efforts on the development of preventive techniques of pest management as alternatives to control techniques. This will require that the CFS and other agencies rejuvenate the capability in insect population dynamics that has been seriously eroded in recent years.

In these remarks, I have tried to outline some of the challenges that I believe will be facing forest entomologists in the 1980's. During the next decade Canadian forestry will come of age. Our forest resources are barely sufficient to meet existing demands and intensive forest management will become the rule rather than the exception. Forest entomologists will be expected to play a more important role than in the past and I am confident that you can meet these challenges. 